\title{
Microbiological and genetic characteristics of Bacillus velezensis bacillibactin-producing strains and their effect on the sulfate-reducing bacteria biofilms on the poly(ethylene terephthalate) surface
}

\author{
Nataliia Tkachuk ${ }^{1, *}$, Liubov Zelena ${ }^{2}$, Oleksandr Lukash ${ }^{1}$, Pavlo Mazur $^{1}$ \\ ${ }^{1}$ T.H. Shevchenko National University “Chernihiv Colehium”, 53, Getman Polubotok Str., Chernihiv, Ukraine 14013 \\ ${ }^{2}$ Danylo Zabolotny Insitute of Microbiology and Virology, NAS of Ukraine 154, \\ Acad. Zabolotny Str., Kyiv, Ukraine, 03143 \\ *corresponding author e-mail: nataliia.smykun@gmail.com
}

Received: 9 March 2021 / Accepted: 2 April 2021

\begin{abstract}
It was evaluated the antibiofilm-forming properties of NUChC C1 and NUChC C2b isolates (from the collection of the Department of Biology of the T.H. Shevchenko National University "Chernihiv Colehium") against the sulfate-reducing bacteria biofilms on the poly(ethylene terephthalate) surface. NUChC $\mathrm{C} 1$ and $\mathrm{NUChC} \mathrm{C} 2 \mathrm{~b}$ isolates were isolated by classical microbiology methods on Postgate's "B" medium and their cultural-morphological, some physiological-biochemical properties and molecular-genetic characteristics were investigated. To identify bacteria the sequencing and analysis of the 16S rRNA gene were carried out. The bacteria were identified as Bacillus velezensis. Based on PCR-ISSR analysis, it was found that the studied bacteria belong to different strains. The 16S rRNA gene sequences were submitted in GenBank as MN508954.1 (NUChC C1), MN749356.1 and MN749357.1 (NUChC $\mathrm{C} 2 \mathrm{~b})$. In the genome of $B$. velezensis the presence and transcriptional activity of the genes for the synthesis of bacillibactin ( $d h b C$, $d h b F)$, fengycin $(f e n A)$ and polyglutamic acid (epsK) were studied. Among these only genes belonging to bacillibactin synthesis operon were detected and only they demonstrated activity. The observed mode of $d h b C$ and $d h b F$ genes expression during 144 hours of cultivation differed between two B. velezensis strains: gradually increasing in NUChC C1 and sharply increased after 24 hours with decreasing on 144th hour in NUChC C2b. Antagonistic properties of the studied strains of $B$. velezensis against sulfate-reducing bacteria Desulfovibrio oryzae NUChC SRB1 and NUChC SRB2 were not observed. Siderophore-producing strains of Bacillus velezensis inhibit the formation of bacterial biofilms on the polymeric material poly(ethylene terephthalate) during its long-term exposure (50 days) in a culture of sulfate-reducing bacteria under conditions of sufficient iron supply. Bacillibactin-producing strains prevent the development of bacterial biofilms on the poly(ethylene terephthalate) surface. This is one of the reasons for the prolongation of the process of poly(ethylene terephthalate) biodegradation in natural ecosystems.
\end{abstract}

Keywords: Bacillus velezensis; biofilm; Desulfovibrio oryzae; bacillibactin; gene expression; poly(ethylene terephthalate).

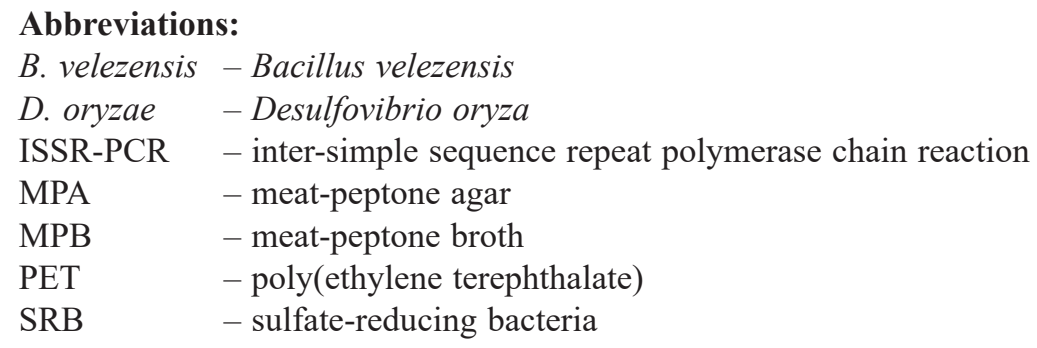




\section{Introduction}

Bacteria on surfaces grow in the form of a biofilm (Bhinu, 2005). Due to the high biochemical activity and the ability to form biofilms, bacteria are actively involved in the degradation of polymeric materials (Saveliev et al., 2011; Rogers et al., 2020). A significant amount of polymeric materials is represented by poly(ethylene terephthalate) (PET), the production of which is growing every year: 2 million tons/year in 2007 and 10 million tons/year in 2012 (Andrushkiv et al., 2012).

Plastic PET bottles are the most common type for packaging soft drinks and water (Filella, 2020). In Ukraine in 2018, out of 203.7 thousand tons of PET bottles that became waste, only 50 thousand tons ended up in waste processing plants (about 25\%), the other 75\% were buried in landfills (Burak \& Kyrychenko, 2020). In addition, due to the low level of environmental awareness and education of the population, a significant part of the used PET-bottles does not end up in landfills, but in natural ecosystems (Lukash, 2015).

The linear structure of PET and the high proportion of aromatic components are chemically inert and increase the strength of the polymer, making it very resistant to degradation by microorganisms (Yoshida et al., 2016). The ability to biodegrade PET is inherent in a small number of species of microorganisms (Yoshida et al., 2016; Vague et al., 2019; Chen et al., 2020; Shulga et al., 2020). The accumulation of PET in the environment creates a global environmental problem (Chen et al., 2020). Among the microorganisms isolated from the plastic surface, there are representatives of sulfate-reducing bacteria (Rogers et al., 2020). Previously, sulfate-reducing bacteria (SRB) Desulfovibrio oryzae were identified as participants in the damage of the metal construction in the soil (Tkachuk et al., 2020).

A number of researchers point out that $\mathrm{Fe}^{3+}$ plays an important role in the formation of microbial biofilms, and the depletion of iron in the environment can slow its formation (Pelchovich et al., 2013; Ali \& Wakte, 2016). Siderophores are low molecular weight compounds that chelate $\mathrm{Fe}^{3+}$ ions, converting iron bound to proteins or water-insoluble compounds into the ionic form of $\mathrm{Fe}^{3+}$ available to microorganisms (Leonov et al., 2016). Many aerobic and facultative anaerobic microorganisms are able to synthesize siderophores, the presence of which changes the structure of the microbial community (Saha et al., 2016).

However, at the moment there are no studies of the processes of SRB biofilms formation on the poly(ethylene terephthalate) surface under the influence of siderophoreproducing strains, therefore, that was an aim of this investigation.

\section{Material and methods}

\subsection{Microorganisms and growing conditions}

Five-day pure cultures of SRB Desulfovibrio oryzae strains NUChC SRB1 and NUChC SRB2, previously isolated from the sulfidogenic community isolated from the soil ferrosphere were used (Tkachuk et al., 2020). The nucleotide sequences were deposited in the GenBank with accession numbers MT102713.1 and MT102714.1 respectively.

To prepare the initial amount of bacteria, they were grown in Postgate's " $C$ " liquid medium (without adding Fe (II) salt) under anaerobic conditions, which were created by pouring the medium to the edges of the tubes and closing them with rubber stoppers. Suspensions with an optical density of $0.5 \mathrm{McF}$ arland were prepared from cultures of the studied strains in sterile isotonic sodium chloride solution. Further we used Postgate's "C" agar or liquid medium with adding Fe (II) salt.

Also in the study NUChC $\mathrm{C} 1$ and NUChC C2b isolates from the collection of the Department of Biology of the T.H. Shevchenko National University "Chernihiv Colehium" were used. Isolation of pure cultures of NUChC C1 and NUChC C2b was performed by the depleting stroke method on Postgate's "B" agar medium. Incubation was carried out under aerobic conditions and a temperature of $29 \pm 2{ }^{\circ} \mathrm{C}$ for 48 hours. The material of the two isolated colonies (NUChC $\mathrm{C} 1$ and NUChC $\mathrm{C} 2 \mathrm{~b}$ isolates) was reseeded into Postgate's "B" liquid medium and incubated under aerobic conditions. After five passages on Postgate's "B" medium, NUChC C1 and NUChC C2b isolates were obtained and used in further studies. The purity of the cultures was checked by microscopy. Bacteria were cultured on meat-peptone agar or meat-peptone broth for 24 hours, 120 hours and 144 hours (specified in each study respectively) aerobically at $29 \pm 2{ }^{\circ} \mathrm{C}$.

\subsection{Detection of bacillibactin ( $d h b C, d h b F)$, fengycin $(f e n A)$ and polyglutamic acid (epsK) synthesis genes in the genome of NUChC $\mathrm{C1}$ and NUChC $\mathrm{C} 2 \mathrm{~b}$ isolates}

Genomic DNA from 24-hour cell cultures of NUChC C1 and NUChC C2b was isolated with GeneJet Genomic DNA Purification Kit (ThermoScientific) according to manufacturer's protocol. The $20 \mu \mathrm{l}$ of PCR reaction mixture contained $10 \mu \mathrm{l}$ of $2 \mathrm{x}$ DreamTaq PCR Master Mix (ThermoScientific), $30 \mathrm{pmol}$ of each primer, and $50 \mathrm{ng}$ of DNA. Amplification was performed at the following temperature: initial denaturation $-5 \mathrm{~min}, 95{ }^{\circ} \mathrm{C} ; 30$ cycles $-10 \mathrm{sec}$, $95{ }^{\circ} \mathrm{C}$; $20 \mathrm{sec}, 57{ }^{\circ} \mathrm{C}$; $35 \mathrm{sec}, 72{ }^{\circ} \mathrm{C}$; final elongation $7 \mathrm{~min}, 72^{\circ} \mathrm{C}$. PCR was performed on Mastercycler Personal 5332 (Eppendorf, Germany). PCR products were checked by separating in $1.7 \%$ agarose gel with ethidium bromide. 
Nucleotide sequences of primers for amplification of $d h b C, d h b F$, eps $K$ and $f e n A$ genes fragments were selected using MEGA6 (Tamura et al., 2013) and Primer3 programs based on known sequences of these genes in representatives of Bacillus subtilis group (Table 1).

Table 1. The oligonucleotides used in the study

\begin{tabular}{|c|c|c|}
\hline Primer & Sequence, 5' - 3' & Reference \\
\hline $\begin{array}{l}d h b C 1 \\
d h b C 2\end{array}$ & $\begin{array}{l}\text { GGAACACCGACTGATCTTGC } \\
\text { CACAACGGATGGTCACGATC }\end{array}$ & This study \\
\hline $\begin{array}{l}d h b F 1 \\
d h b F 2\end{array}$ & $\begin{array}{c}\text { ACCCAGCTGCAAAATCAAGG } \\
\text { TCGCCGCTTCAAAATCTAGC }\end{array}$ & This study \\
\hline $\begin{array}{l}\text { fenA1 } \\
\text { fenA2 }\end{array}$ & $\begin{array}{l}\text { GACAGGGGCTGTCTCTGAAG } \\
\text { TGCATCCCTGATAAAAAGGC }\end{array}$ & $\begin{array}{l}\text { (Grabova et al., } \\
\text { 2016) }\end{array}$ \\
\hline $\begin{array}{l}\text { eps } K 1 \\
\text { epsK2 }\end{array}$ & $\begin{array}{l}\text { CATGGTTTACGTTCCGGGTG } \\
\text { AGCGGAAACTGAATGATCGC }\end{array}$ & This study \\
\hline
\end{tabular}

\subsection{Analysis of $d h b C$ and $d h b F$ genes expression and determining the number of catecholate-type siderophores in supernatant from MPB cultures of NUChC C1 and NUChC C2b}

To analyze gene expression bacterial cells of two strains were cultivated for 144 hours in MPB at $29 \pm 2{ }^{\circ} \mathrm{C}$. Samples for the analysis were taken after 24 hours and 144 hours of cultivation. RNA was isolated using TRIzol Reagent (Invitrogen) according to the manufacturer' protocol and followed by DNaseI treatment. cDNA was synthesized from $1 \mu \mathrm{g}$ of RNA using random hexanucleotide primers and M-MLV reverse transcriptase. The total volume of qPCR reaction mix was $10 \mu \mathrm{l}$ and contained $5 \mu \mathrm{l}$ of PowerUp ${ }^{\mathrm{TM}}$ SYBR $^{\mathrm{TM}}$ Green Master Mix (Applied Biosystems ${ }^{\mathrm{TM}}$ ), 20 pmol of each primer and $2 \mu \mathrm{l}$ of cDNA template. qPCR was performed with QuantStudio ${ }^{\text {TM }} 3$ Real-Time PCR System (Applied Biosystems) under temperature conditions recommended by the manufacturer. 16S rRNA gene was considered as endogenous reference (Zelena et al., 2014). No template control and duplicate samples for each gene (16S rRNA, $d h b C$ and $d h b F$ ) were included in the run. Relative genes expression level was calculated with $2^{-\Delta \Delta \mathrm{Ct}}$ method (Livak \& Schmittgen, 2001) with QuantStudio ${ }^{\mathrm{TM}}$ Real-Time PCR software program (Applied Biosystems). The statistical significance of gene expression between samples was calculated using t-test. The primer specificity and dimer formation were checked with melting curve analysis.

Neilands spectrophotometric testing was used to determine the content of siderophores of the catecholate type (which includes bacillibactin) (Sujatha \& Ammani, 2013). We measured the absorbance at $490 \mathrm{~nm}$, consistent with the data from Sujatha \& Ammani (2013), that at this wavelength the absorption maximum indicates the presence of catecholate siderophores.

\subsection{Determination of antagonistic properties of $\mathrm{NUChC} \mathrm{C} 1$ and $\mathrm{NUChC} \mathrm{C} 2 \mathrm{~b}$ isolates against sulfate-reducing bacteria}

The method of filling bacterial colonies of NUChC $\mathrm{C} 1$ and NUChC $\mathrm{C} 2 \mathrm{~b}$ isolates with agar medium containing the test organisms (D. oryzae NUChC SRB1 and NUChC SRB2) was used (Egorov, 1965). For this purpose, daily cultures of NUChC C1 and NUChC C2b isolates were sown with a Drygalski spatula on the surface of meat-peptone agar in Petri dishes to obtain separate colonies. After the colonies of microorganisms were well developed (growing in a thermostat for 120 hours at a temperature of $29 \pm 2$ ${ }^{\circ} \mathrm{C}$ ), around the colonies that were grown, Postgate's " $\mathrm{C}$ " agar medium was poured with added test-organisms - SRB D. oryzae strains NUChC SRB1 and NUChC SRB2 $\left(10^{6}\right.$ cells/ml medium).

After solidification of the medium with test-cultures anaerobic conditions were created by the method of Shturm L.D. in the modification of Duda V.I. (Zvyagintsev et al., 2005). Petri dishes were placed at $29 \pm 2{ }^{\circ} \mathrm{C}$ for 5 days. The development of bacterial test-cultures was visually observed.

\subsection{A biofilm assay}

To study the intensity of biofilm formation on the PET surface, $10 \times 10 \mathrm{~mm}$ samples of PET were cultured in Postgate's " $C$ " liquid medium ( $76 \%$ of the volume) with the addition of meat-peptone broth (MPB) or a supernatant from MPB cultures of NUChC C1 isolate (or NUChC C2b isolate) obtained after centrifugation for $10 \mathrm{~min}$ at 10,000 rpm ( $22 \%$ of the volume) and a culture of D. oryzae NUChC SRB1 (2\% of the volume) during 50 days.

A biofilm assay (indirect measurement of bacterial biofilm biomass by crystal violet adsorption/desorption) was used (Stepanović et al., 2000). The strains were classified into adhesion categories as was described by Stepanović et al. (2000). Statistical analysis of the obtained results was performed using the statistical module of Microsoft Office Excel 2010.

\subsection{Identification of $\mathrm{NUChC} \mathrm{C} 1$ and $\mathrm{NUChC} \mathbf{C 2 b}$ isolates}

Investigation of cultural-morphological and some physiological-biochemical properties of isolates. Light microscopy (Delta Optical Genetic Pro microscope) at magnification $(\times 400$ and $\times 1000)$ and electron microscopy (BS-540 electron microscope) (Tesla, Czechoslovakia) at $\times 16000$ magnification were used to study the morphology of NU- 
ChC C1 and NUChC C2b bacteria. Preparations of microbial cells were Gram-stained in the Kalina's modification to determine gram affiliation by Hansen's method for staining spores (Dikiy et al., 2002). The strains were grown on Postgate's "B" medium, meat-peptone broth (MPB) and meat-peptone agar (MPA). Morphological analysis of colonies was performed according to the conventional scheme. Studies of the presence of catalase and oxidase were performed by conventional methods (Dikiy et al., 2002).

Molecular-genetic analysis of isolated strains. To identify bacteria the sequencing and analysis of 16S rRNA gene were carried out. DNA isolation, amplification with $27 \mathrm{~F}$ and $1492 \mathrm{r}$ primers, sequencing of $16 \mathrm{~S}$ rDNA in both directions, phylogenetic analysis procedures were performed as described in (Tkachuk et al., 2017). The nucleotide sequences were deposited in GenBank as Bacillus velezensis with accession numbers MN508954.1 (NUChC C1), MN749356.1 and MN749357.1 (NUChC C2b). The basic sequence statistics of $16 \mathrm{~S}$ rDNA, including conserved sites, variable sites, parsimony informative sites, singleton sites and calculation of pairwise distances were analyzed with MEGA6 software (Tamura et al., 2013).

Genome variability and strain differentiation were analyzed by ISSR-PCR (Inter-simple sequence repeat polymerase chain reaction) (Tkachuk et al., 2020).

\section{Results and discussion}

\subsection{Microbiological characteristics of NUChC C1 and NUChC C2b isolates}

Colonies of NUChC $\mathrm{C} 1$ isolate when cultured on Postgate's "B" agar medium under aerobic conditions were superficial, of grayish-beige color, irregular shape, solid consistency, size 3-4 $\mathrm{mm}$. The edges of the colonies were wavy, the structure is fine-grained, the center of the colonies was darker than the edges.

On the MPA, the colonies of NUChC C1 and NU$\mathrm{ChC} \mathrm{C} 2 \mathrm{~b}$ isolates had a diameter of 3 and $1 \mathrm{~mm}$, respectively, were of beige color, round ( $\mathrm{NUChC} \mathrm{C1)} \mathrm{or} \mathrm{irregular}$ shape (NUChC C2b) (Fig. 1). The profile of the colonies is flattened, the surface is shiny, smooth, the structure is fine-grained. The edges of the colonies are uneven, wavy. The consistency is soft. Bacteria are gram-positive motile rods with rounded ends, peritrichous, $8.0 \pm 0.9 \mu \mathrm{m}$ long (NUChC C1) and $7.0 \pm 0.5 \mu \mathrm{m}$ (NUChC C2b), single, in pairs or chains (4 or more cells), form endospores (Fig. 1).

Both isolates are catalase-positive and oxidase-negative.

Therefore, microbiological characteristics according to Bergey's Manual of Systematic Bacteriology (De Vos et al., 2009) prove that the isolated bacteria can belong to the Bacillus genus.

\subsection{Genome variability of the new isolates}

The results of PCR-ISSR analysis are presented in Figure 2. The comparison of the sets of amplification fragments obtained (in number and size) between isolates showed the presence of common and unique for each sample amplicons. The size of PCR products ranged from 600 to 3000 bp $\left((\mathrm{GA})_{9} \mathrm{C}\right)$ and from 300 to $2000 \mathrm{bp}\left((\mathrm{GA})_{8} \mathrm{~T}\right)$. The total spectrum of amplification products with primer $\left((\mathrm{GA})_{9} \mathrm{C}\right)$ consisted of 7 fragments, 3 of which were polymorphic. The percentage of polymorphic loci using primer $(\mathrm{GA})_{8} \mathrm{~T}$ was $62.5 \%, 5$ of 8 amplicons. Thus, the bacteria NUChC $\mathrm{C} 1$ and NUChC $\mathrm{C} 2 \mathrm{~b}$ do belong to different strains.
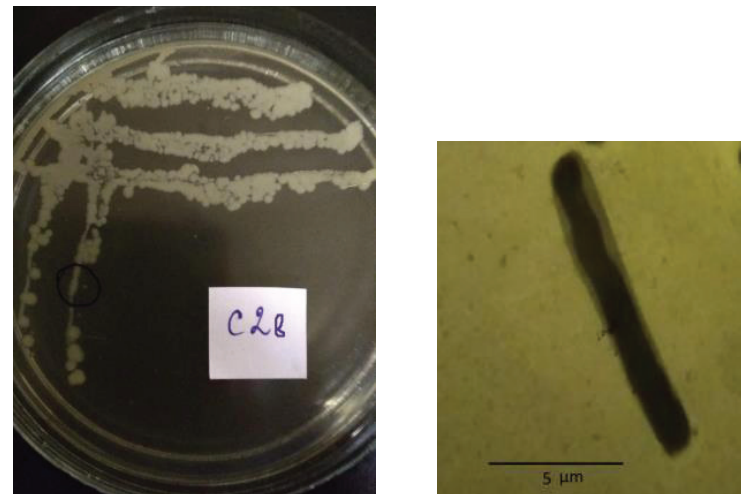

b

Figure 1. Test isolates (colonies on MPA (24 hours) and microphotographs of the cells (electron microscopy, $\times 16000)$ : a $-\mathrm{NUChC}$ $\mathrm{C} 1 ; \mathrm{b}-\mathrm{NUChC} \mathrm{C} 2 \mathrm{~b}$ (scale bar: $5 \mu \mathrm{m}$ ) 
3.3. The presence and activity of bacillibactin, fengycin and polyglutamic acid synthesis genes in the genome of NUChC $\mathrm{C} 1$ and NUChC $\mathrm{C2b}$ strains

Bacillus bacteria are known to be widespread in the environment, including soil, and are able to produce a variety of important natural substances (Saxena et al., 2020). They are used to improve plant growth and development and as biocontrol agents, due to their ability to synthesize substances with antifungal, antibacterial and nematocidal activity (Mongkolthanaruk, 2012; Ramlucken et al., 2020; Saxena et al., 2020). Such substances include cyclic lipopeptide fengycin, siderophore bacillibactin (Mongkolthanaruk, 2012) and polyglutamic acid (Hsueh et al., 2017).

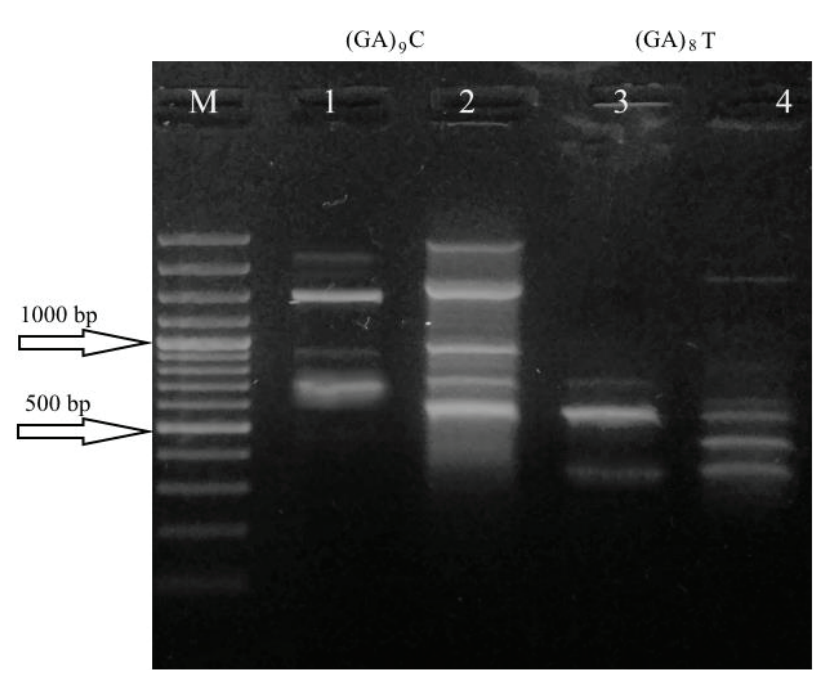

Figure 2. The electrophoregram of amplification products with primers to short nucleotide repeats: $\mathrm{M}-\mathrm{DNA}$ ladder (ThermoScientific); 1, 3 - NUChC C1; 2, 4-NUChC $\mathrm{C} 2 \mathrm{~b}$
The study of the presence of genes for the synthesis of bacillibactin $(d h b C, d h b F)$, fengycin $(f e n A)$ and polyglutamic acid (epsK) in the genome of isolates showed that the studied strains have only the gene for the synthesis of bacillibactin (Fig. 3). Bacillibactin biosynthesis relies on the $d h b A-F$ operon encoding enzymes that carry out four sequential reactions converting 3-chorismate to bacillibactin (Abe et al., 2019; Qin et al., 2019). Comparative analysis of $d h b C$ and $d h b F$ genes expression revealed differences in mRNA abundance between two strains. NUChC $\mathrm{C} 2 \mathrm{~b}$ strain demonstrated the higher transcriptional activity after 24 hours of cultivation compared to NUChC C1 strain but the level of $d h b C$ and $d h b F$ expression was decreasing on $144^{\text {th }}$ hour in NUChC C2b strain while it was still increasing in NUChC C1 strain (Fig. 4).

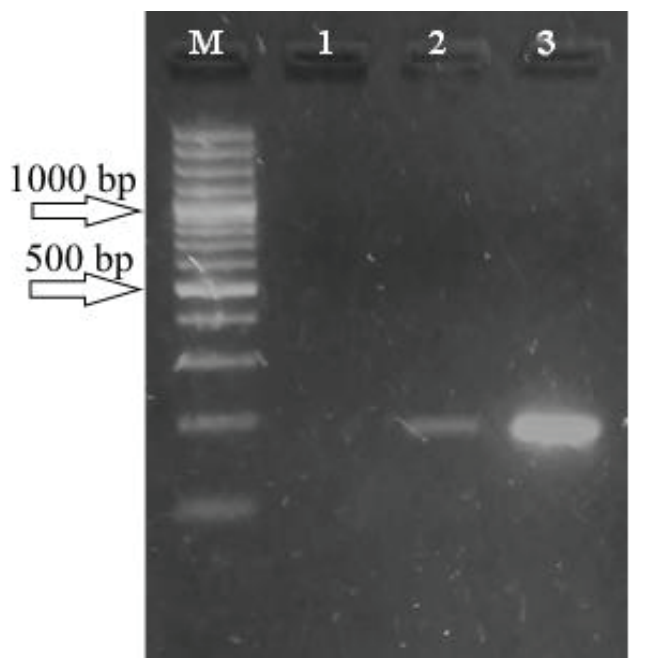

Figure 3. The electrophoregram of amplification products of the $d h b F$ gene fragment. $\mathrm{M}-$ a molecular weight marker; 1 - the negative control; 2 - NUChC C1; 3 - NUChC $\mathrm{C} 2 \mathrm{~b}$

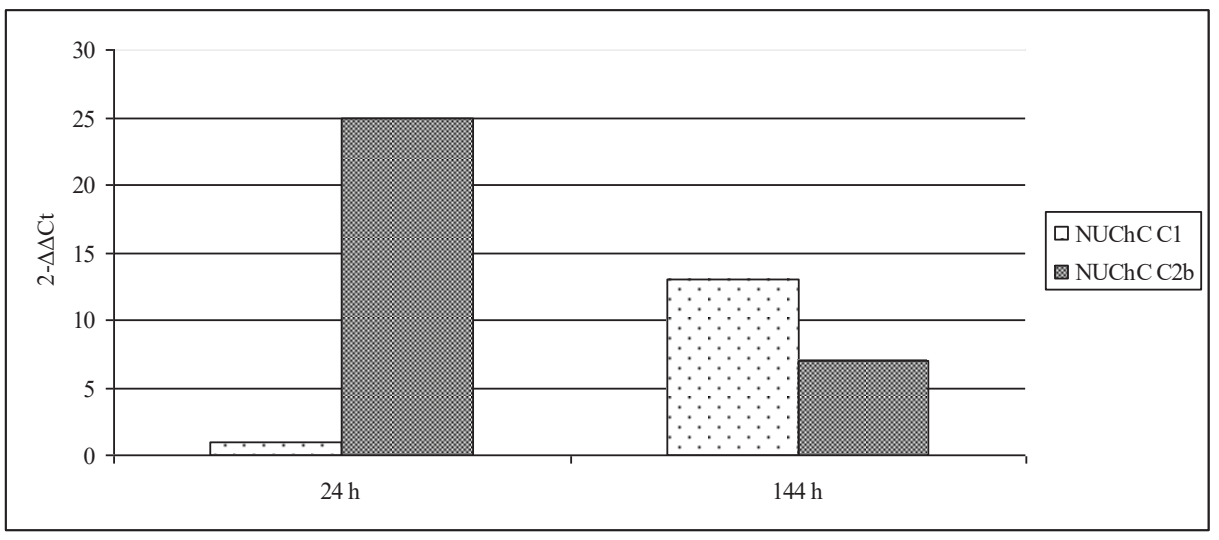

Figure 4. Relative total $d h b C$ and $d h b F$ genes expression level in test strains. The least total gene expression level was taken as 1 (NUChC $\mathrm{C} 1)$. The differences between strains are statistically significant at $\mathrm{p} \leq 0.05$ 
The results of the investigation of the number of siderophores of the catecholate type in the culture fluid of the studied strains are shown in Table 2.

Table 2. Optical density $\left(\mathrm{OD}_{490}\right)$ of the supernatant of the studied NUChC $\mathrm{C} 1$ and $\mathrm{NUChC} \mathrm{C} 2 \mathrm{~b}$ strains by spectrophotometric testing of Neilands

\begin{tabular}{|l|c|c|}
\hline \multirow{2}{*}{ A variant of the experiment } & \multicolumn{2}{|c|}{ OD } \\
\cline { 2 - 3 } & $\mathbf{2 4}$ hours & $\mathbf{1 4 4}$ hours \\
\hline MPB (without bacteria) & 0.045 & 0.050 \\
\hline $\begin{array}{l}\text { Supernatant from MPB culture } \\
\text { of NUChC C1 }\end{array}$ & 0.050 & 0.055 \\
\hline $\begin{array}{l}\text { Supernatant from MPB culture } \\
\text { of NUChC C2b }\end{array}$ & 0.064 & 0.063 \\
\hline
\end{tabular}

It was found that optical density of the supernatant from MPB culture of NUChC C2b strain is $15-28 \%$ higher than NUChC C1 strain (Table 2). This indicates a higher number of catecholate-type siderophores in NUChC C2b strain culture at both the 24th and 144th hours of cultivation.

\subsection{The intensity of biofilm-formation and growth of $D$. oryzae under the influence of NUChC C1 and NUChC C2b strains}

A number of researchers point to the fact that bacteria of the genus Bacillus are able to inhibit the development of microorganisms that actively biodegrade materials and their formation of biofilms (Jayaraman et al., 1999a; Jayaraman et al., 1999b; Ornek et al., 2002; Korenblum et al., 2008; Bano \& Qazi, 2011; Korenblum et al., 2012; Du et al., 2014; Aïmeur et al., 2015; Wadood et al., 2015).

Therefore, we investigated the intensity of SRB biofilm formation on the surface of PET samples in the presence of a supernatant from MPB cultures of NUChC $\mathrm{C} 1$ and

NUChC C2b, which contained siderophore bacillibactin. The results are presented in Figure 5 and 6.

It was found that the supernatant of the studied NUChC $\mathrm{C} 1$ and NUChC C2b strains significantly inhibits (2 times) the formation of a biofilm on the surface of PET bacteria D. oryzae NUChC SRB1 (Fig. 6). It should be noted that the inhibition of SRB biofilm formation on PET by the supernatant of both strains was the same, despite the observed different level of expression of bacillibactin siderophore synthesis genes and the difference in the number of catecholate-type siderophores (Fig. 4, Table 2). Thus, a supernatant from MPB cultures of NUChC $\mathrm{C} 1$ and NUChC $\mathrm{C} 2 \mathrm{~b}$ strains inhibits the formation of SRB biofilm on the poly(ethylene terephthalate) surface.

Therefore, we further investigated the antagonistic properties of our isolates against SRB D. oryzae. The experiment was performed by filling the antagonist colonies with Postgate's " $\mathrm{C}$ " agar medium containing test-organisms. It was found that SRB D. oryzae strains NUChC SRB1 and NUChC SRB2 develop around colonies of isolates - sterile areas are absent. Therefore, the antagonistic properties of the studied isolates against SRB were not observed.

\subsection{Identification of isolates by $16 \mathrm{~S}$ rRNA gene sequence analysis}

As a result of molecular-genetic analysis of isolates, fragments of the 16S rRNA gene with a size of $567 \mathrm{bp}$ (NUChC C1), 665 and 179 bp (NUChC C2b) were sequenced. The initial comparison of the obtained sequences using the BLAST program showed $99 \%$ similarity with different members of the genus Bacillus: B. methylotrophicus, B. amyloliquefaciens subsp. plantarum, B. velezensis. Based on the nucleotide sequences of the 16S rRNA gene of type strains of the most similar species and studied isolates using the Neighbor-Joining algorithm and the two-parameter Kimura's model, a dendrogram of genetic similarity was constructed (Fig. 7).

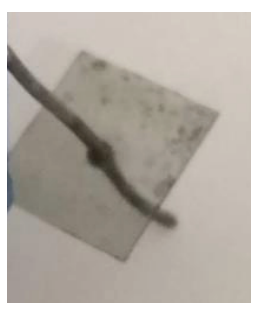

c

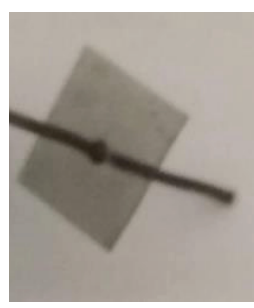

d

Figure 5. Samples of PET with the formed biofilm of sulfate-reducing bacteria: $a-$ control; $b-\mathrm{SRB} 1 ; \mathrm{c}-\mathrm{SRB} 1+\mathrm{C} 1 ; \mathrm{d}-\mathrm{SRB} 1+\mathrm{C} 2 \mathrm{~b}$ 


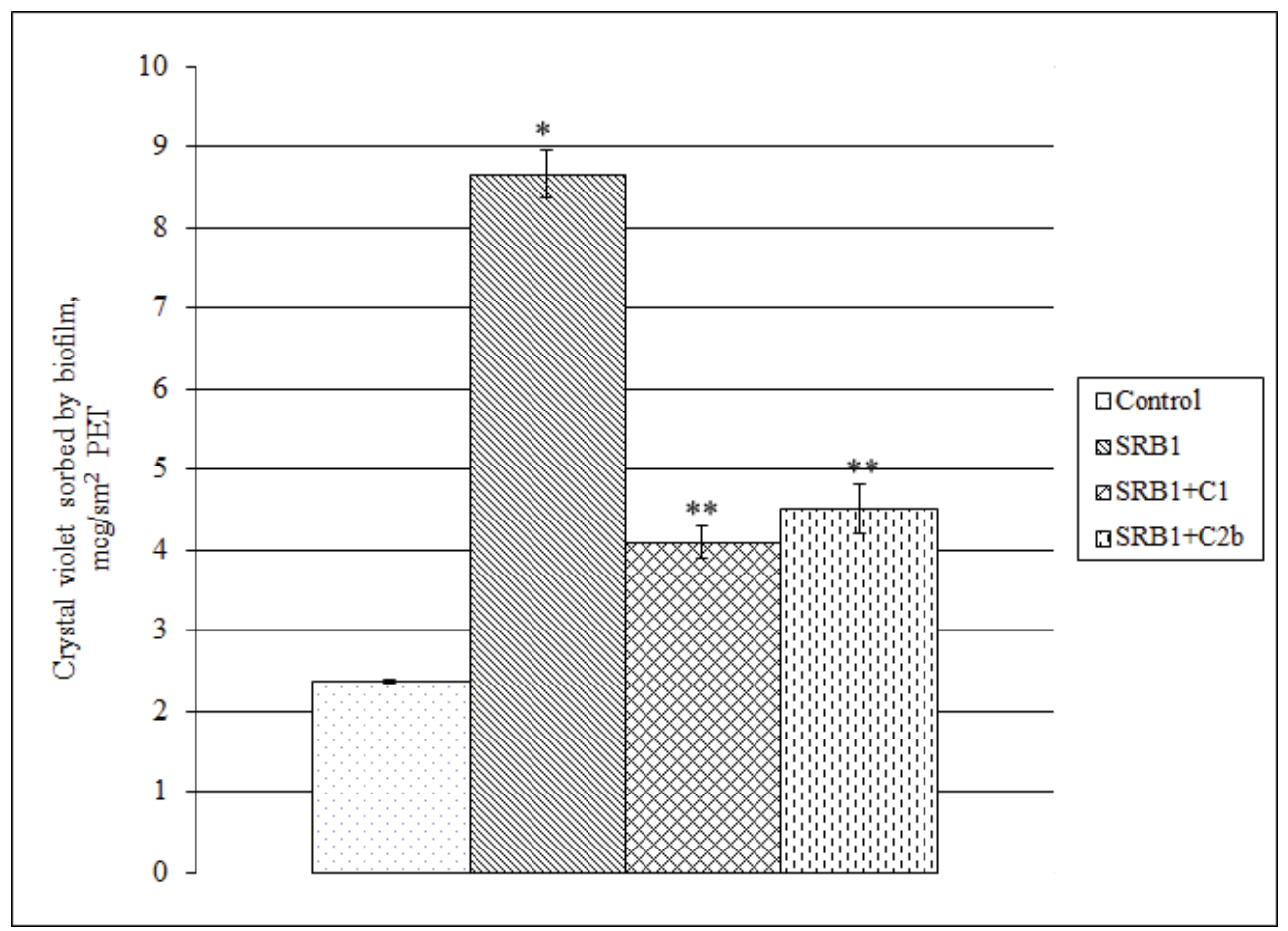

Figure 6. Biofilm-forming ability of sulfate-reducing bacteria of strain D. oryzae NUChC SRB1 on the poly(ethylene terephthalate) in the presence of supernatant from MPB cultures of NUChC C1 and NUChC C2b (50 days of cultivation). Note: the differences are significant * compared to the control, ** compared to the control and SRB1 at $\mathrm{p} \leq 0.05$

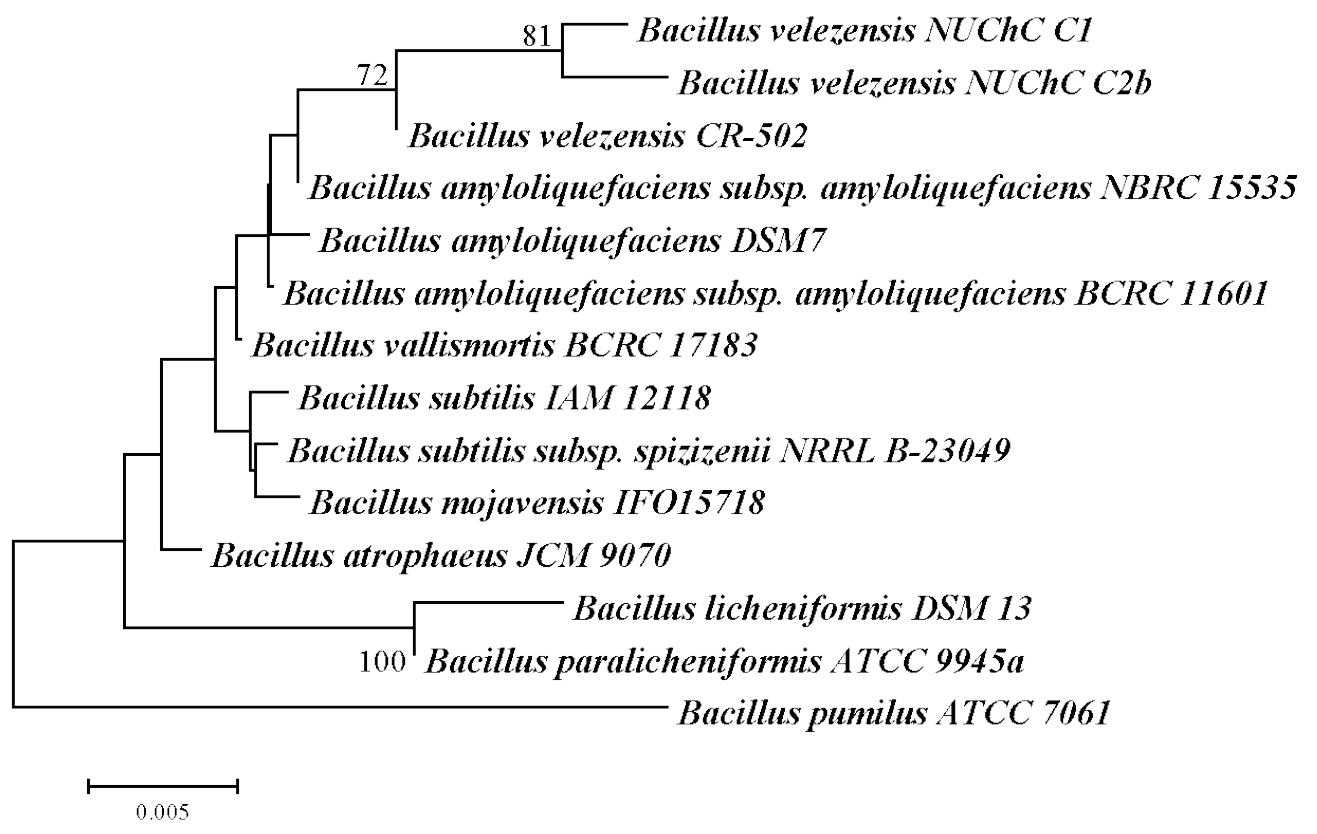

Figure 7. Results of phylogenetic analysis of isolates of NUChC C1 and NUChC C2b and other members of the genus Bacillus 
All these species of the genus Bacillus combined into one cluster. As can be seen from Figure 7, isolates of NUChC $\mathrm{C} 1$ and NUChC C2b were included in one subcluster with the species Bacillus velezensis, which confirms their belonging to this species. It should be noted that today the species names of $B$. amyloliquefaciens subsp. plantarum, B. methylotrophicus, "B. oryzicola", $B$. methylotrophicus subsp. plantarum are accepted as heterotypic synonyms of $B$. velezensis (Dunlap et al., 2016; NCBI, 2019).

Therefore, NUChC $\mathrm{C} 1$ and NUChC C2b isolates have been identified as Bacillus velezensis for a number of microbiological and genetic characteristics.

Antibiofilming and antifouling properties of $B$. velezensis bacteria have been noted in the works of a number of researchers (Khan et al., 2016; Wang et al., 2019; Yoo et al., 2019). In particular, B. velezensis WY has the ability to quench the quorum sensing due to the significant activity of degradation of acylhomoserinlactone - a kind of signaling molecule required for the development of biofilm (Khan et al., 2016). It is possible that our B. velezensis NUChC C1 and NUChC C2b strains also have the ability to quench the quorum sensing, because, despite the antibiofilm-forming properties of SRB biofilms, their antagonistic properties against these bacteria have not been noted.

In addition, representatives of $B$. velezensis are producers of bacillibactin (Rabbee et al., 2019) - a siderophore of the catecholate type (Hertlein et al., 2014). The ability to form bacillibactin is also the characteristic of our studied strains of $B$. velezensis NUChC C1 and NUChC C2b. Siderophores are low molecular weight compounds that chelate $\mathrm{Fe}^{3+}$ ions, convert iron bound to proteins or waterinsoluble compounds into an ionic form of $\mathrm{Fe}^{3+}$ available to microorganisms (Leonov et al., 2016).

A number of researchers point to the fact that iron (III) plays an important role in the formation of microbial biofilms, and the depletion of iron in the environment can slow down the formation of biofilms (Harrison \& Buckling, 2009; Cai et al., 2010; Glick et al., 2010; Pelchovich et al., 2013; Ali \& Wakte, 2016). Analyzing recent publications, Rizzi et al. (Rizzi et al., 2019) conclude that biofilm formation and Fe uptake are closely related, and that biofilm formation may play an important mechanistic role in Fe uptake by siderophore in biofilm-forming bacteria. Harrison and Buckling showed (Harrison \& Buckling, 2009) that clones of Pseudomonas aeruginosa which were defected from cooperative production of iron-scavenging siderophores were deficient in biofilm formation. The presence of such clones in mixed biofilms with a wild-type clone led to reduced biofilm mass (Harrison \& Buckling, 2009). Researchers noted (Ali \& Wakte, 2016) that the supply of sufficient iron by siderophore insists the strain to form strong biofilm.
While the strain produce low to moderate amount of siderophore shown weak biofilm formation. This reveals that low amount of siderophore insufficient to transport optimum iron for growth and biofilm development under iron restricted condition (Ali \& Wakte, 2016). Along with this it is noted that the biofilm formation and development are strongly dependent on iron availability, and, for this reason, iron chelation may be an encouraging and novel approach to control biofilm (Ribeiro \& Simões, 2019). The antibacterial activity may be achieved by the ability of non-metabolizable iron chelators to diminish iron that could otherwise be used for bacterial replication. Very effective chelators may deprive pathogenic microorganisms of the iron essential for growth. Thus, iron chelators can be used as therapeutic compounds (Ribeiro \& Simões, 2019).

\section{Conclusions}

NUChC $\mathrm{C} 1$ and NUChC C2b isolates from the collection of the Department of Biology of the T.H. Shevchenko National University "Chernihiv Colehium" belong to different strains, have the presence and different transcriptional activity of genes of bacillibactin synthesis operon, and, accordingly, different production of siderophore bacillibactin. According to the complex of microbiological and genetic traits, the studied bacteria were identified as Bacillus velezensis. The siderophore-producing Bacillus velesensis strains inhibit the formation of sulfate-reducing bacteria biofilms on the polymeric material poly(ethylene terephthalate) with its long-term exposure (50 days) in a culture of bacteria under conditions of sufficient iron supply. Antagonistic properties of the studied strains against sulfate-reducing bacteria $D$. oryzae NUChC SRB1 and D. oryzae NUChC SRB2 were not observed.

Bacillibactin-producing strains prevent the development of bacterial biofilms on the poly(ethylene terephthalate) surface. This is one of the reasons for the prolongation of the process of poly(ethylene terephthalate) biodegradation in natural ecosystems.

\section{Acknowledgements}

We are sincerely grateful to the leading engineer Volodymyr Strekalov (Institute of agricultural microbiology and agroindustrial production of National Academy of agricultural sciences of Ukraine) for carrying out of electronic microscopy, the students Vladyslava Kikhtenko and Anastasiya Samkova (T.H. Shevchenko National University "Chernihiv Colehium") for excellent technical assistance. 


\section{References}

Abe T., Kobayashi K., Kawamura Sh., Sakaguchi T., Shiiba K. \& Kobayashi M., 2019, Dipeptide synthesis by internal adenylation domains of a multidomain enzyme involved in nonribosomal peptide synthesis. The Journal of General and Applied Microbiology 65(1): 1-10. doi: 10.2323/jgam.2018.03.001

Aïmeur N., Houali K., Hamadou L., Benbrahim N. \& Kadri A., 2015, Influence of strain Bacillus cereus bacterium on corrosion behaviour of carbon steel in natural sea water. The International Journal of Corrosion Processes and Corrosion Control, 50(8): 579-588. doi:10.1179/17 43278215Y.0000000022

Ali S.S. \& Wakte P.S., 2016, Biofilm formation and siderophore production by Pseudomonas Aeruginosa isolated from wounds infection. International Journal of New Technology and Research 2(9): 20-23.

Andrushkiv B., Vovk I. \& Pohaidak O., 2012, Udoskonalennia ekonomichnoho instrumentariiu poshuku novykh resursiv $\mathrm{v}$ umovakh postradianskoho suspilstva [Improving the economic tools for finding new resources in post-Soviet society]. Halytskyi Ekonomichnyi Visnyk 3(36). (in Ukrainian)

Bano A.Sh. \& Qazi J.I., 2011, Soil Buried Mild Steel Corrosion by Bacillus cereus-SNB4 and its Inhibition by Bacillus thuringiensis-SN8. Pakistan Journal of Zoology 43(3): 555-562.

Bhinu V.S., 2005, Insight into biofilm-associated microbial life. Journal of Molecular Microbiology and Biotechnology 10: 15-21. doi: 10.1159/000090344

Burak O.M. \& Kyrychenko A.Iu., 2020, Stvorennia punktiv pryiomu PET-pliashok dlia udoskonalennia protsesu upravlinnia vidkhodamy $\mathrm{v}$ Ukraini [A creative point for receiving PET bottles to improve the waste management process in Ukraine]. Materialy Mizhnarodnoi naukovo-praktychnoi internet-konferentsii "Pidpryiemnytstvo ta biznes-administruvannia”, m. Kharkiv, 2020. (in Ukrainian)

Cai Y., Wang R., An M.-M. \& Liang B.-B., 2010, Irondepletion prevents biofilm formation in Pseudomonas aeruginosa through twitching mobility and quorum sensing. Brazilian Journal of Microbiology 41(1): 3741. doi: $10.1590 / \mathrm{S} 1517-83822010000100008$

Chen Zh., Wang Y., Cheng Y., Wang X., Tong S., Yang H. \& Wang Z., 2020, Efficient biodegradation of highly crystallized polyethylene terephthalate through cell surface display of bacterial PETase. Science of The Total Environment 709: 136138. doi: 10.1016/j.scitotenv.2019.136138

De Vos P., Garrity G.M., Jones D., Krieg N.R., Ludwig W., Rainey F.A., Schleifer K.-H. \& Whitman W.B. (eds.), 2009, The Firmicutes, 2nd ed., Vol. 3. Bergey's Manual of Systematic Bacteriology. Springer, New York, NY, USA.

Dikiy I.L., Holupyak I.Y. \& Sidorchuk I.I., 2002, Mikrobiologiya. Rukovodstvo k laboratornyim zanyatiyam [Microbiology. A guide to laboratory exercises]. Izdatel'stvo Nacional'nogo farmacevticheskogo universiteta “Zolotye stranicy", Har'kov, 444 pp. (in Russian)

Du J., Li S., Liu J. \& Yu M., 2014, Corrosion behavior of steel Q235 co-influenced by Thiobacillus thiooxidans and Bacillus. Journal of Beijing University of Aeronautics and Astronautics 40(1): 31-38.

Dunlap Ch.A., Kim S.-J., Kwon S.-W. \& Rooney A.P., 2016, Bacillus velezensis is not a later heterotypic synonym of Bacillus amyloliquefaciens; Bacillus methylotrophicus, Bacillus amyloliquefaciens subsp. plantarum and 'Bacillus oryzicola' are later heterotypic synonyms of Bacillus velezensis based on phylogenomics. International Journal of Systematic and Evolutionary Microbiology 66: 1212-1217. doi: 10.1099/ijsem.0.000858

Egorov N.S., 1965, Mikrobyi antagonistyi i biologicheskie metodyi opredeleniya antibioticheskoy aktivnosti [Microbes antagonists and biological methods for determining antibiotic activity]. Vysshaya Shkola, Moskva, 211 pp. (in Russian)

Filella M., 2020, Antimony and PET bottles: Checking facts. Chemosphere 261: 127732. doi: 10.1016/j.chemosphere.2020.127732

Glick R., Gilmour C., Tremblay J., Satanower S., Avidan O, Déziel E., Greenberg E.P., Poole K. \& Banin E., 2010, Increase in rhamnolipid synthesis under iron-limiting conditions influences surface motility and biofilm formation in Pseudomonas aeruginosa. Journal of Bacteriology 192(12): 2973-80. doi: 10.1128/JB.01601-09

Grabova A.Yu., Dragovoz I.V., Zelena L.B., Tkachuk D.M. \& Avdeeva L.V., 2016, Antifungal activity and gene expression of lipopeptide antibiotics in strains of $\mathrm{Ba}$ cillus genus. Biopolymers and Cell 32(1): 41-48. doi: 10.7124/bc.00090B

Harrison F. \& Buckling A., 2009, Siderophore production and biofilm formation as linked social traits. The ISME Journal 3:632-634. doi: 10.1038/ismej.2009.9

Hertlein G., Müller S., Garcia-Gonzalez E., Poppinga L., Süssmuth R. D. \& Genersch E., 2014, Production of the catechol type siderophore bacillibactin by the honey bee pathogen Paenibacillus larvae. PloS One 9(9): e108272. doi:10.1371/journal.pone.0108272

Hsueh Y.-H., Huang K.-Y., Kunene S.Ch. \& Lee T.-Y., 2017, Poly- $\gamma$-glutamic acid synthesis, gene regulation, phylogenetic relationships, and role in fermentation, International Journal of Molecular Sciences 18: 2644. doi: 10.3390/ijms18122644

Jayaraman A., Hallock P.J., Carson R.M., Lee C.C., Mansfeld F.B. \& Wood T.K., 1999a, Inhibiting 
sulfate-reducing bacteria in biofilms on steel with antimicrobial peptides generated in situ. Applied Microbiology and Biotechnology 52: 267-275. doi: 10.1007/s002530051520

Jayaraman A., Mansfeld F.B. \& Wood T.K., 1999b, Inhibiting sulfate-reducing bacteria in biofilms by expressing the antimicrobial peptides indolicidin and bactenecin. Journal of Industrial Microbiology and Biotechnology 22: 167-175. doi: 10.1038/sj.jim.2900627

Khan R., Shen F., Khan K., Liu L.X., Wu H.H., Luo J.Q. \& Wan Y.H., 2016, Biofouling control in membrane filtration system by newly isolated novel quorum quenching bacterium, Bacillus methylotrophicus sp. WY. RSC Advances 6: 28895-28903. doi: 10.1039/C6RA01663D

Korenblum E., Sebastián G.V., Paiva M.M., Coutinho C.M.L.M., Magalhães F.C.M., Peyton B.M. \& Seldin L., 2008, Action of antimicrobial substances produced by different oil reservoir Bacillus strains against biofilm formation. Applied Microbiology and Biotechnology 79: 97-103. doi: 10.1007/s00253-008-1401-x

Korenblum E., de Araujo L.V., Guimaraes C.R., de Souza L.M., Sassaki G., Abreu F., Nitschke M., Lins U., Freire D.M.G., Barreto-Bergter E. \& Seldin L., 2012, Purification and characterization of a surfactin-like molecule produced by Bacillus sp. H2O-1 and its antagonistic effect against sulfate reducing bacteria. BMC Microbiology 12: 252-264. doi: 10.1186/1471-2180-12-252

Leonov V.V., Mironov A.Yu., Ananina I.V., Rubalskaya E.E. \& Sentyurova L.G., 2016, Mikrobnye siderofory: struktura, svojstva, funkcii [Siderophores of microbes: structure, properties and functions]. Astrahanskiy Meditsinskiy Zhurnal 11(4): 24-37. (in Russian)

Livak K.J. \& Schmittgen T.D., 2001, Analysis of relative gene expression data using real-time quantitative PCR and the $2^{-\triangle \Delta C T}$ method. Methods 25: 402-408. doi: $10.1006 /$ meth.2001.1262

Lukash O.V., 2015, Stykhiini smittiezvalyshcha v okolytsiakh silskykh naselenykh punktiv Chernihivshchyni: vplyv na pryrodni ekosystemy ta sotsialnyi aspekt problem [Spontaneous landfills in the vicinity of rural settlements in Chernihiv region: impact on natural ecosystems and the social aspect of the problem], Formuvannia stratehii povodzhennia $\mathrm{z}$ vidkhodamy $\mathrm{v}$ umovakh detsentralizatsii vlady: problemy ta perspektyvy realizatsii na rivni mistsevykh hromad: zbirka materialiv natsionalnoho forumu "Povodzhennia z vidkhodamy v Ukraini: zakonodavstvo, ekonomika, tekhnolohii" (10-11 lystopada 2015 r., m. Kyiv). Tsentr ekolohichnoi osvity ta informatsii, Kyiv, p. 66-68. (in Ukrainian)

Mongkolthanaruk W., 2012, Classification of Bacillus Beneficial Substances Related to Plants, Humans and Animals. Journal of Microbiology and Biotechnology 22(12): 1597-1604. doi: 10.4014/jmb.1204.04013
NCBI, 2019, Taxonomy [online]. Website https://www. ncbi.nlm.nih.gov/Taxonomy/ [accessed 15 November 2019]

Ornek D., Jayaraman A., Syrett B.C., Hsu C.H., Mansfeld F.B. \& Wood T.K., 2002, Pitting corrosion inhibition of aluminum 2024 by Bacillus biofilms secreting polyaspartate or g-polyglutamate. Applied Microbiology and Biotechnology 58: 651-657. doi: 10.1007/s00253-002-0942-7

Pelchovich G., Omer-Bendori S. \& Gophna U., 2013, Menaquinone and iron are essential for complex colony development in Bacillus subtilis. PLoS One 8: e79488. doi: 10.1371/journal.pone.0079488

Qin Y., He Y., She Q., Larese-Casanova Ph., Li P., Li P. \& Chai Y., 2019, Heterogeneity in respiratory electron transfer and adaptive iron utilization in a bacterial biofilm. Nature Communications 10: 3702. doi: 10.1038/ s41467-019-11681-0

Rabbee M.F., Ali Md.S., Choi J., Hwang B.S., Jeong S.Ch. \& Baek K.-h., 2019, Bacillus velezensis: A Valuable Member of Bioactive Molecules within Plant Microbiomes. Molecules 24: 1046. doi:10.3390/molecules 24061046

Ramlucken U., Roets Y., Ramchuran S.O., Moonsamy G., van Rensburg Ch.J., Thantsh M.S. \& Lalloo R., 2020, Isolation, selection and evaluation of Bacillus spp. as potential multi-mode probiotics for poultry. The Journal of General and Applied Microbiology, Article ID 2019.11.002. doi: 10.2323/jgam.2019.11.002

Ribeiro M. \& Simões M., 2019, Siderophores: a novel approach to fight antimicrobial resistance, [in:] D. Arora, Ch. Sharma, S. Jaglan, E. Lichtfouse (eds.), Pharmaceutical from microbes: impact on drug discovery. Springer International Publishing, p. 99-120.

Rizzi A., Roy S., Bellenger J.-Ph. \& Beauregard P.B., 2019, Iron Homeostasis in Bacillus subtilis Requires Siderophore Production and Biofilm Formation. Applied and Environmental Microbiology 85(3): e0243918. doi: 10.1128/AEM.02439-18

Rogers K.L., Carreres-Calabuig J.A., Gorokhova E. \& Posth N.R., 2020, Micro-by-micro inretactions: How microorganisms influence the fate of marine microplastics. Limnology and Oceanography Letters 5: 18-36. doi:10.1002/lol2.10136

Saha M., Sarkar S., Sarkar B., Sharma B.K., Bhattacharjee S. \& Tribedi P., 2016, Microbial siderophores and their potential applications: a review. Environmental Science and Pollution Research International 23(5): 3984-99. doi: 10.1007/s11356-015-4294-0.

Saveliev Yu.V., Yanovych I.V., Akhranovych O.R. et al., 2011, Stvorennia ta zastosuvannia dehraduiuchykh za umov navkolyshnoho seredovyshcha poliuretaniv na osnovi vuhlevodiv [Creation and application of polyurethanes, degrading under environmental conditions, 
based on carbohydrates], Polimernyi Zhurnal, 33(3): 205-217. (in Ukrainian)

Saxena A.K., Kumar M., Chakdar H., Anuroopa N. \& Bagyaraj D.J., 2020, Bacillus species in soil as a natural resource for plant health and nutrition. Journal of $A p$ plied Microbiology 128(6): 1583-1594. doi: 10.1111/ jam.14506

Shulga N.V., Tkachuk N.V. \& Zelena L.B., 2020, Biodegradatsiya polietilentereftalatu [Biodegradation of polyethylene terephthalate], Krok u nauku: doslidzhennya u galuzi prirodnicho-matematichnih distsiplin ta metodik yih navchannya: Zbirnik tez dopovidey Vseukrayinskoyi naukovo-praktichnoyi konferentsiyi studentiv, aspirantiv i molodih uchenih (20 listopada 2020 r., m. Chernihiv). NUChK imeni T.H. Shevchenka, Chernihiv, p. 74-75. (in Ukrainian)

Stepanović S., Vuković D., Dakić I., Savić B. \& ŠvabićVlahović M., 2000, A modified microtiter-plate test for quantification of staphylococcal biofilm formation. Journal of Microbiological Methods 40: 175-179. doi:10.1016/s0167-7012(00)00122-6

Sujatha N. \& Ammani K., 2013, Siderophore production by the isolates of fluorescent Pseudomonas. International Journal of Current Research and Review 5(20): $1-7$.

Tamura K., Stecher G., Peterson D., Filipski A. \& Kumar S., 2013, MEGA6: Molecular Evolutionary Genetics Analysis Version 6.0. Molecular Biology and Evolution 30: 2725-2729. doi: 10.1093/molbev/mst197.

Tkachuk N., Zelena L., Mazur P. \& Lukash O., 2020, Genotypic, physiological and biochemical features of Desulfovibrio strains in a sulfidogenic microbial community isolated from the soil of ferrosphere. Ecological Questions 31(2): 79-88. doi:10.12775/EQ.2020.016

Tkachuk N.V., Zelena L.B., Parminska V.S., Yanchenko V.O. \& Demchenko A.M., 2017, Identyfikatsiia heterotrofnykh bakterii ferosfery gruntu ta yikh chutlyvist do pestytsydu linuron [Identification of heterotrophic bacteria isolated from soil ferrosphere and their sensitivity to the pesticide linuron]. Mikrobiolohichnyi Zhurnal 79(4): 75-87. doi: 10.15407/microbiolj79.04.075 (in Ukrainian)

Vague M., Chan G., Roberts C., Swartz N.A., \& Mellies J.L., 2019, Pseudomonas isolates degrade and form biofilms on polyethylene terephthalate (PET) plastic. bioRxiv, 647321. doi: 10.1101/647321.

Wadood H.Z., Rajasekar A., Ting Y.-P. \& Sabari A.N., 2015, Role of Bacillus subtilis and Pseudomonas aeruginosa on Corrosion Behaviour of Stainless Steel. Arabian Journal for Science and Engineering 40: 18251836. doi: 10.1007/s13369-015-1590-4

Wang L., Yu L. \& Lin C., 2019, Extraction of Protease Produced by Sea Mud Bacteria and Evaluation of Antifouling Performance. Journal of Ocean University of China (Oceanic and Coastal Sea Research) 18: 11391146. doi: 10.1007/s11802-019-3843-4

Yoo Y., Seo D.-H., Lee H., Cho E.-S., Song N.-E., Nam T.G., Nam Y.-D. \& Seo M.-J., 2019, Inhibitory effect of Bacillus velezensis on biofilm formation by Streptococcus mutans. Journal of Biotechnology 298: 57-63. doi: 10.1016/j.jbiotec.2019.04.009

Yoshida S., Hiraga K., Takehana T., Taniguchi I., Yamaji H., Maeda Y., Toyohara K., Miyamoto K., Kimura Y. \& Oda K., 2016, A bacterium that degrades and assimilates poly(ethylene terephthalate). Science 351(6278): 1196-1199. doi: 10.1126/science.aad6359

Zelena L., Gretsky I. \& Gromozova E., 2014, Influence of ultrahigh frequency irradiation on Photobacterium phosphoreum luxb gene expression. Central European Journal of Biology 9: 1004-1010. doi: 10.2478/s11535014-0347-5

Zvyagintsev G.D., Babieva I.P. \& Zenova G.M., 2005, Biologiya pochv [Biology of soils]. Izdatel'stvo Moskovskogo universiteta, Moskva, 445 pp. (in Russian) 